\title{
COMPARING DEPRESSION LEVELS AMONG DIABETICS; INSULIN USERS VS NON-INSULIN USERS
}

1,2,4,5

LUMHS Research Forum

Liaquat University of Medical \& Health Sciences,

Jamshoro

3. Department of Medicine,

Liaquat University Hospital, Jamshoro

Liaquat University of Medical \& Health

Sciences,

Jamshoro

Correspondence Address:

Aatir H. Rajput

LUMHS Research Forum

Liaquat University of Medical \& Health

Sciences,

Jamshoro

aatirh.rajput@gmail.com

Article received on: 27/02/2016

Accepted for publication:

15/05/2016

Received after proof reading:

04/07/2016

\begin{abstract}
Aatir H. Rajput', Muhammad Muneeb ${ }^{2}$, M. Iqbal Shah ${ }^{3}$, Nehan Syed ${ }^{4}$, Abid Ali ${ }^{5}$
ABSTRACT... Introduction: This descriptive (cross-sectional) study compares depression levels among diabetic patients using different treatments (insulin users v/s non-insulin) at Hyderabad. Objectives: This study evaluates the depressive symptoms and their association with education, medication adherence, demographic variables and health complaints among diabetics based on type of therapy used. Setting: Liaquat University Hospital, Hyderabad. Material and methods: 264 patients visiting Liaquat University Hospital, Hyderabad and different diabetic clinics at Hyderabad in the months of February and March, 2014 were included in the study via simple random sampling. 106 patients $(40.16 \%)$ of the total sample are females and $158(59.84 \%)$ are males. Patients were interviewed to attain information about age, sex, onset and type of diabetes, type of medication used (insulin or oral hypoglycemic), glycemic control, medication adherence and diabetes associated health complaints. Results: $36.36 \%$ of the people in the sample were insulin users while $63.64 \%$ were not. Out of 96 insulin users, $30.2 \%$ of the sample has DM-type 1 and $69.8 \%$ have DM-type 2. Mean depression level of male insulin users is 21.93 while that of females is 22.81. Conclusion: Demographic factors, low education, additional health complaints and low medication adherence also significantly contributed to depression levels. Mental health assessment of diabetics should be made a part of routine clinical assessment at primary healthcare clinics to decrease adversarial consequences among diabetic patients.
\end{abstract}

Key words: Diabetes type II, non-adherence, depression, retrospective analysis, noncompliance, depressive symptoms in diabetes.

Article Citation: Rajput AH, Muneeb M, Shah MI, Syed N, Ali A. Comparing depression levels among diabetics; insulin users vs non-insulin users. Professional Med $\mathrm{J}$ 2016;23(7):870-874. DOI: 10.17957/TPMJ/16.3317

\section{INTRODUCTION}

Diabetes Mellitus is the most significant cause of non-traumatic limb amputation, blindness among adults and newly reported cases of end stage renal disease. ${ }^{1}$ It is the sixth main cause of death and it also assist in developing stroke and cardiac related mortality and morbidity. ${ }^{1}$ Diabetes mellitus is a diverse metabolic disorder characterized by chronic high blood glucose level. Inadequate insulin action on peripheral target tissues leads to the defective metabolism of carbohydrates, fats and proteins. This is either due to insufficient insulin production (type 1) or increased insulin resistance (type 2). Insulin level among type 2 patients is greater than type 1 patients but not high enough to counteract the insulin resistance created at the post receptor level mainly. ${ }^{1}$ Among all the chronic medical problems, diabetes mellitus may be greatly influenced by depression.
Diabetes is the most metabolically active disease which can influence the psychological state. ${ }^{2}$ Comorbid depression also leads to poor quality of life. ${ }^{4}$ Evidences suggest that depression is highly associated with insufficient glycemic control, impaired insulin sensitivity and is consequential co-morbid condition for diabetic patient. ${ }^{3}$ Diabetic patients are two times more prone to develop depressive symptoms than non-diabetic patients. ${ }^{3,5,8}$ Previous studies showed that depression alters the glucose metabolism and increases the risk of diabetes. Depression lessens the insulin sensitivity and increases its resistance in the body. ${ }^{5}$ Major depressive disorder predisposes to the development of micro- and macro vascular complications in diabetic patients. ${ }^{7}$ The cost of co-morbid diabetes and depression is huge. Due to its chronic nature, about $95 \%$ diabetes treatment is carried by the patients themselves. ${ }^{2}$ 
Therefore, comorbid depression is related with worsened diabetes complications by less dietary care, poor glucose monitoring, low compliance, decreased exercise, hypoglycemia, multi-drug regimens, health care expenses and ultimately lead to death. ${ }^{2,6}$

This study was designed to compare the depression levels among diabetic patients using different modes of treatment (Insulin users V/s Non-Insulin users) at Hyderabad and also to evaluate the depressive symptoms and its relation with knowledge, compliance, demographic variables and health complaints among patients based on the therapy used.

\section{METHODS}

\section{Study design and period}

This study was a descriptive cross-sectional psycho-social analysis which employed a questionnaire based interview. The survey was conducted from February to March 2014.

\section{Sample size}

The sample size calculated for this study was of 264 and hence 158 males and 106 females were approached. Data was collected via simple random convenient sampling.

\section{Study area and population}

The survey was conducted at Liaquat University Hospital, Hyderabad and different diabetic clinics at Hyderabad. The out-door patients were approached and were informed of the details of the present study, consent of the patients was obtained by way of filling and signing of a consent form.

\section{Assessment of Depression}

Self-administered structured questionnaire was designed including Hamilton Depression Rating Scale for adults and Children's Depression Rating Scale revised for calculating depression level in adults and children respectively. Patients were interviewed to attain information about age, sex, onset and type of diabetes, type of medication used (Insulin or oral hypoglycemic), glycemic control, medication adherence and diabetes associated health complaints.

\section{Inclusion Criteria}

This study included the patients aged more than 7 years, patients who were diagnosed with diabetes and have been consuming medication for more than 1 month. Patients belonging to different socio-economic status of Hyderabad (only) and who willingly agreed to take part in this study were included.

\section{Exclusion criteria}

This study did not employed those patients who are off their medication or have switched over the alternative medicines (other than insulin or oral-hypoglycemic). Patients with disability not associated with diabetes or with any concurrent chronic diseases (but not a complication of diabetes, e.g. Hepatitis, Cardiovascular diseases (CVD), Neurological Disorders, Liver and Kidney diseases) were not included in the study.

\section{Data analysis, entry and interpretation}

Data was entered and analyzed on Microsoft Excel 2013 and SPSS (Statistical package for the social sciences) version 16.

\section{RESULTS}

In this study, 89\% patients had Type II Diabetes while $11 \%$ patients suffered from Type I Diabetes. $36.36 \%$ of patients in the total sample were Insulin users while $63.64 \%$ were Non-Insulin users. Out of total Insulin users $30.2 \%$ were suffering from Type I Diabetes while the remaining $69.7 \%$ suffered from Type II Diabetes. Mean depression level of children aged $>12$ was 46.25 (using insulin twice a day as mode of treatment).Overall mean depression level among insulin users was found to be 21.93. Mean depression level of adult male insulin users was 21.52 while adult female insulin users was 22.81 , markedly greater than the mean depression level of adult non-insulin users i.e. 19.77. Mean depression level of adult male noninsulin users was 19.85 while adult female noninsulin users was 19.36. Among type 1 diabetic patients, $29 \%$ of patients stick to their medication while $71 \%$ patients do not adhere to their medication. Whereas among the type 2 diabetic 
patients, $63 \%$ adhere to the medication while $37 \%$ do not. $78 \%$ of the insulin users have ever thought of abandoning the therapy while among the noninsulin users this percentage is comparatively low which is $57 \%$. This study presented an average percentile of literacy with 29\% patients with primary education, $8 \%$ patients with secondary education, $17 \%$ patients with college education, $26 \%$ patients with university level education and $21 \%$ patients with no education at all.

Type of Diabetic Patients

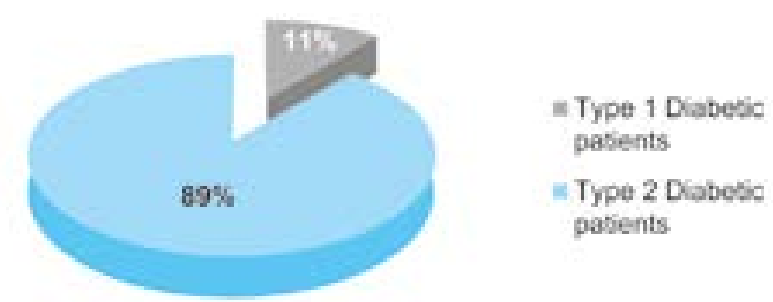

Figure-1. Percentage of Diabetic patients found in this study.

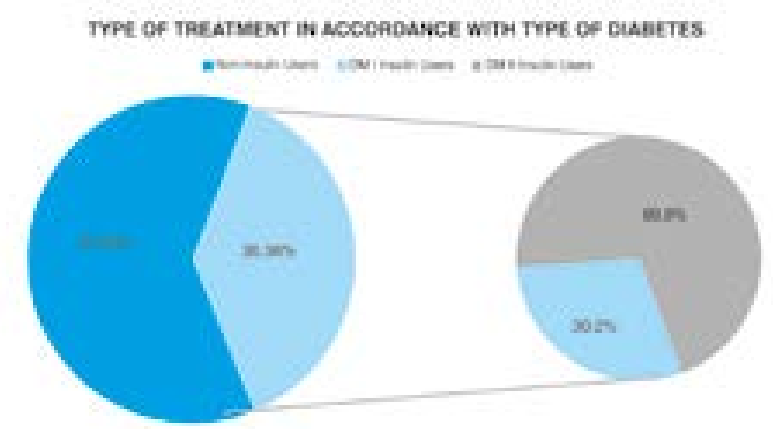

Figure-2. Type of treatment in accordance with type of Diabetes.

\begin{tabular}{|c|c|c|c|}
\hline & $\begin{array}{c}\text { Overall } \\
\text { Mean } \\
\text { Depression } \\
\text { Level }\end{array}$ & $\begin{array}{c}\text { Mean } \\
\text { Depression } \\
\text { Level in } \\
\text { Males }\end{array}$ & $\begin{array}{c}\text { Mean } \\
\text { Depression } \\
\text { Level in } \\
\text { Females }\end{array}$ \\
\hline $\begin{array}{c}\text { Among Insulin } \\
\text { Users }\end{array}$ & 21.93 & 21.52 & 22.81 \\
\hline $\begin{array}{c}\text { Among Non- } \\
\text { Insulin Users }\end{array}$ & 19.77 & 19.85 & 19.36 \\
\hline Table-I. Mean depression levels among patients.
\end{tabular}

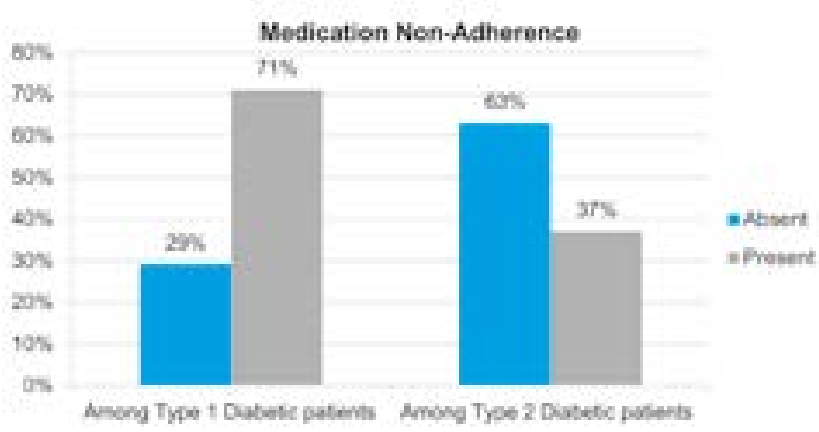

Figure-3. Medication Non-adherence among Type 1 and Type 2 Diabetic patients.

\section{DISCUSSION}

According to this study, the prevalence of comorbid depression with diabetes is significant in the population of Hyderabad (Pakistan) especially among the insulin users Type 2 diabetic patients. Previous studies suggests that diabetic patients are twice more prone to develop depression than non-diabetic patients. ${ }^{8,9}$ Among type 1 diabetes, poor glycemic control is the major cause of depression while in type 2 diabetic patients diabetic complications arising lead to depression. ${ }^{8}$ Meta-analysis of certain studies also mentioned that depressed patients have $3 \%$ more chance of developing type 2 diabetes than non-depressed patients. ${ }^{10}$ Data revealed that increased depressive symptoms ranging from 21 to $27 \%$ are present among type 1 and type 2 diabetes respectively. ${ }^{3}$ Another study also mentioned that type 2 diabetic patients suffer from depression more than type 1 diabetic patients. ${ }^{9}$ Due to the ongoing nature of type 2 diabetes, oral hypoglycemic agents are insufficient alone to control the glucose level. Therefore, injectable insulin regimens are also used and adherence to this medication is often low. Regardless of comprehensive therapy in type 2 diabetes, the appropriate glycemic control (approved by American Diabetes Association) is found in only $50 \%$ of patients. The major outcome of poor adherence is lowered glycemic control and decreased insulin sensitivity leading to the early development of complications of diabetes which may involve micro-vascular and macro-vascular diseases. Psychological insulin resistance is also found in one study of insulin users. ${ }^{11}$ It has been 
reported that the depressed patients are 3 times more non-adherent to their medication than the non-depressed patients. ${ }^{12}$ Research from National Health Interview study revealed that diabetic patients suffering from comorbid depression have 7.15 times more chance of developing functional impairment. The rate of early mortality among diabetic patients with co-morbid depression has increased to 2.3 times in individuals with either condition alone. The medical cost over patients with co-morbid depression is 4.5 times greater than patients with diabetes only. ${ }^{3}$ Depression is related with aggrevation of somatic symtoms and disability, consumption of multiple medical regimens, increased mortality and morbidity from major medical illness. ${ }^{13}$ On the other hand, data from a study showed the association of depression with variable 9 symptoms, its relation with 2-3 hyperglycemic symptoms and 5-6 hypoglycemic symptoms. ${ }^{14}$ The prevalence of depression is found more in females rather than males. Major depression and elevated depressive symptoms are found in proportion of 11 and 31 $\%$ in diabetic patients. Therefore, it has been estimated that every third person suffering from diabetes also has enough depressive symptoms to alter his mental, physical and functional states and compliance. ${ }^{9}$

\section{CONCLUSION}

As insulin use has become so regular and common due to the progressive nature of type 2 +diabetes, its adherence is quite beneficial in glycemic control though but it is poor. It leads to aggression in the symptoms and early development of the complications of diabetes contributing to depression and depressive symptoms. There are several reasons for this poor compliance as age, psychological insulin resistance, cost of medication and poor education.

\section{Copyright@ 15 May, 2016.}

\section{REFERENCES}

1. Musselman D.L, Betan E, Larsen H, Phillips L.S, Relationship of depression to diabetes types 1 and 2: Epidemiology, biology and treatment, Biol Psychiatry, 2003; 54; 317-329.

2. Ciechanowski P.S, Katon W.J, Russo J.E, Depression and diabetes impact of depressive symptoms on adherence, function and costs, Arch Intern Med, 2000;160;21;3278-3285.

3. Groot M.D, Kushnick M, Doyle T, Merrill J, Mcglynn M, Shubrook J, Schwartz F, Depression among adults with diabetes: Prevalence, Impact and Treatment options, Diabetes Spectra, 2010:23(1);15-18.

4. Bell R.A, Smith S.L, Arcury T.A, Snively B.M, Stanfford J.M, Quandt S.A, Prevalence and correlates of depressive symptoms among rural older African Americans, Native Americans and Whites with Diabetes, Diabetes Care, 2005;28(4);823-829.

5. Everson-Rose S.A, Meyer P.M, Powell L.H, Pandey D, Torrens J.I, Kravitz H.M, Bromberger J.T, Matthews K.A, Depressive symptoms, Insuin resistace and risk of diabetes in women at Midlife, Diabetes Care, 2004; 27(12);2856-2862.

6. Groot M D, Pinkerman B, Wagner J, Hockman E, Depression Treatment and Satisfaction in a Multicultural sample of Type 1 and Type 2 Diabetic Patients, Diabetes Care, 2006; 29(3); 549-553.

7. Lustman P.J, Clouse R.E, Freedland K.E, Management of Major Depression in Adults with Diabetes: Implications of recent Clinical Trials, Semin Clin Neuropsychiatry,1998;3(2);102-114.

8. Groot M.D, Lustman P.J, Depression among AfricanAmericans with Diabetes; A dearth of studies, Diabetes Care, 2001; 24(2); 407-408.

9. Anderson R.J, Freesland K.E, Clouse R.E, Lustman P.J, The Prevalence of Co-morbid Depression in Adults with Diabetes; A meta-Analysis, Diabetes Care, $2001,124(6), 1069-1078$.

10. Knol M.J, Twisk W.R, Beekman A.T.F, Heine R.J, Snoek F.J, Pouwer F, Depression as a risk factor for the onset of Type 2 Diabetes Mellitus; A meta-analysis, Diabetolgia, 2006;49(5),837-845.

11. Perez L.E.G, Alvarez M, Dilla T, Guille V.G, Beltra D.O, Adherence to therapies in patients with Type 2 Diabetes, Diabetes Ther,2013;4;175-194.

12. Katon W.J, Depreesion and Chronic Medical IIIness, J Clin Psychiatry, 1990; 513-11.

13. Katon W, Sullivan, Depression and Chronic Illness, J Clin Psychiatry,1990;51(3-11); discussion 12-4

14. Lustman P.J, Clouse R.E, Carney R.M, Depression and reporting of Diabetes Symptoms, The International Journal of Psychiatry in Medicine,1998; 18(4); 295-303. 


\section{"Sticks in a bundle are unbreakable."}

\section{Bondei Proverb}

\section{AUTHORSHIP AND CONTRIBUTION DECLARATION}

\begin{tabular}{|c|c|c|c|}
\hline Sr. \# & Author-s Full Name & Contribution to the paper & Author $=\mathbf{s}$ Signature \\
\hline 1 & Aatir H. Rajput & $\begin{array}{l}\text { Conception of the work and acquisition } \\
\text { analysis and interpretation of data for the } \\
\text { work. Drafting the work and critical revision } \\
\text { for important intellectual content and final } \\
\text { approval of the version to be published and } \\
\text { accountability for all aspects of the works. }\end{array}$ & \\
\hline 2 & Muhammad Muneeb & $\begin{array}{l}\text { Help in designing the work and acquisition, } \\
\text { analysis and interpretation of data for } \\
\text { the work. Drafting the work and final } \\
\text { approval of the version to be published and } \\
\text { accountability for all aspects of the work. }\end{array}$ & \\
\hline 3 & M. Iqbal Shah & $\begin{array}{l}\text { Help in designing the work and acquisition, } \\
\text { analysis and interpretation of data for } \\
\text { the work. Drafting the work and final } \\
\text { approval of the version to be published and } \\
\text { accountability for all aspects of the work. }\end{array}$ & \\
\hline 4 & Nehan Syed & $\begin{array}{l}\text { Help in designing the work and acquisition, } \\
\text { analysis and interpretation of data for } \\
\text { the work. Drafting the work and final } \\
\text { approval of the version to be published and } \\
\text { accountability for all aspects of the work. }\end{array}$ & \\
\hline 5 & Abid Ali & $\begin{array}{l}\text { Help in designing the work and acquisition, } \\
\text { analysis and interpretation of data for } \\
\text { the work. Drafting the work and final } \\
\text { approval of the version to be published and } \\
\text { accountability for all aspects of the work. }\end{array}$ & \\
\hline
\end{tabular}

